Department of Food Hygiene,

Faculty of Veterinary Medicine,

Assiut University, Assiut, Egypt.

Corresponding author: dr.mohammedsayed@yahoo.com

\title{
PCR METHOD FOR DETECTION OF mecA GENE IN METHICILLIN-RESISTANCE Staphylococcus aureus (MRSA) STRAINS ISOLATED FROM MILK AND MILKING SURROUNDING ENVIRONMENT
}

(With 10 Tables and 2 Figures)

\author{
By \\ M. SAYED and S. KOTB*
}

* Department of Animal Hygiene, Faculty of Veterinary Medicine, Assiut

University, Assiut, Egypt.

(Received at 14/10/2010)

طريقة تفاعل البلمرة المتسلسل للكثف عن جين mecA في عترات المكور العنقودي الذهبي المقاوم للميشيسيلان (MRSA) المعزولة من اللبن وبيئة الحلب المئ المحيطة

\section{محمد سبي، صابر قطب}

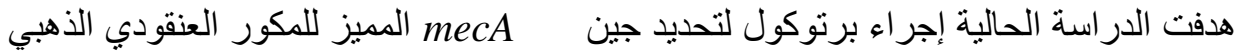

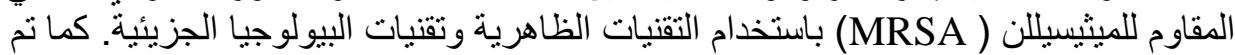
تصميم هذه الدر اسة لتحديد نسب إنتشار عنر ات mecA-positive MRSA في اللبن وفي البيئة

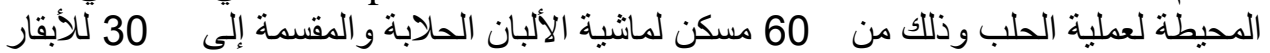
وكذللك 30 للجاموس. وقد تم تجميع عدد 308 عينة شملت 150 عينة من مساكن الأبقار الحلابة من من منابة

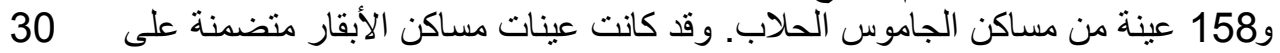

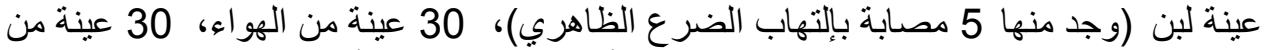

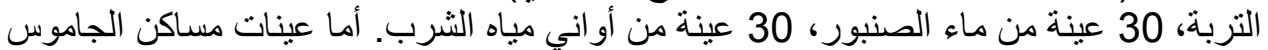

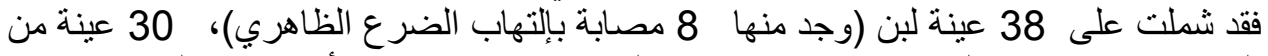

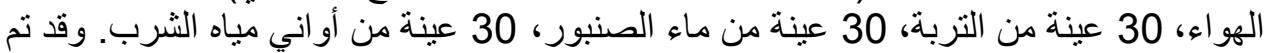

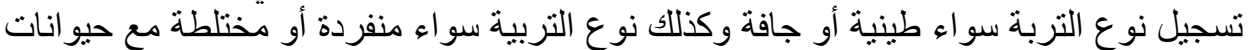

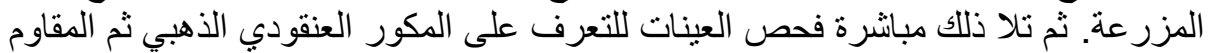

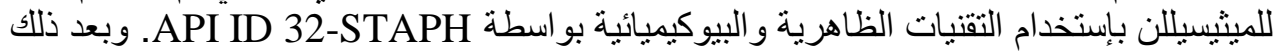
تم فحص كل العترات باستخدام البيولوجيا الجزيئية للكثف عن الجين الخاص بونية بمقاومة المينثيسيللن و الذي يسمى جين PBP2a mecA (بروتين مرتبط البنيسيللين) وذللك بإستعمال تقنية تفاعل البلمرة المتسلسل PCR. وقد أوضحت النتائج المكتسبة أن 139 و 139 عينة كَانت إيجابية للمكور

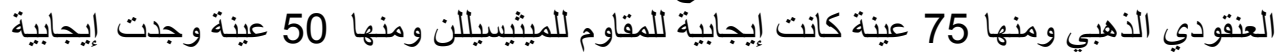
للعتر ات mecA-positive MRSA ومقسمة إلى 14 عينة لبن و36 عينات بيئية. وكانت عينات 
60

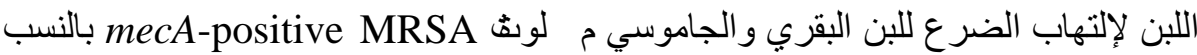

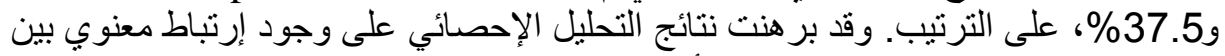

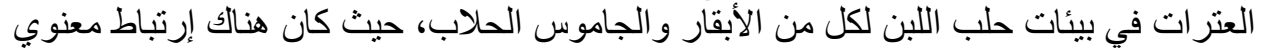

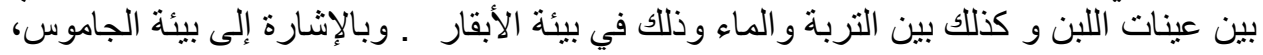

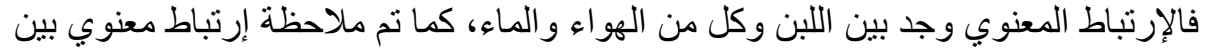

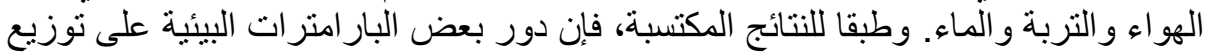

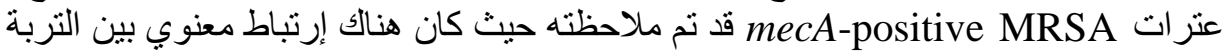
الطينية وكل من نوعي التربية وكذلك بين التربة الجافة و التربية المختلطة وذلك الكان لكل من بيئات حلب اللبن للأبقار و الجاموس الحلاب.

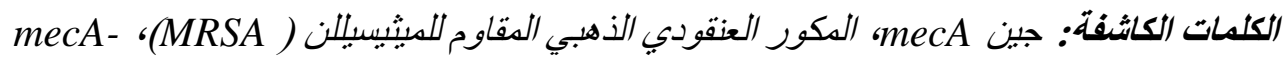

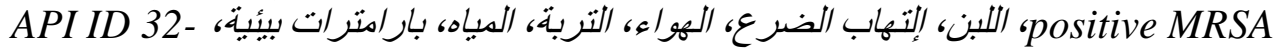

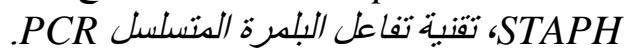

\section{SUMMARY}

The aim of the present investigation was to run a protocol to detect mecA gene that characterizing methicillin-resistant Staphylococcus aureus (MRSA) using phenotypic and genotypic molecular techniques. Also, this study was designed to determine the prevalence of mecA-positive MRSA strains in milk and its surrounding milking environment from 60 dairy cattle houses including 30 for cows and 30 for buffalos. Therefore, 308 samples were collected including 150 samples from cows' houses and 158 from buffalos' houses. The samples from cows' houses were 30 milk samples (5 of them were mastitic), 30 air samples, 30 floor samples of different soil types, 30 tap water samples and 30 pail water samples. The samples from buffalos' houses were 38 milk samples ( 8 of them were mastitic), 30 air samples, 30 floor samples of different soil types, 30 tap water samples and 30 pail water samples. It was also recorded the floor type either muddy or dry and the rearing type either separate or mixed with farm animals. Thereafter, the collected samples were examined directly for identification of Staph. aureus and then MRSA using phenotypically and biochemically with API ID 32-STAPH. All the identified strains were tested genotypically for resistance to oxacillin by detection of the gene encoding methicillin-resistant that called mecA gene PBP2a (penicillinbinding protein) using PCR assay. The obtained results revealed that, 139 samples were positive for Staph. aureus including 75 samples were positive for MRSA which included 50 samples were found mecA-positive MRSA divided as 14 milk samples and 36 milking surrounding environmental samples. The mastitic milk samples of cows and buffalos were contaminated with $m e c A$-positive MRSA in percentages of 60 and 
$37.5 \%$, respectively. The statistical analysis results proved a significant correlation among the isolated strains in the milking surrounding environments of both dairy cows and buffalos; in which, a significant correlation between milk samples and also between soil and water in the cows' environment. With attention to the buffalos' environment, a significant correlation was found between clinically normal milk and both of air and water; also, a significant correlation among air, soil and water was noticed. According to the obtained results, the role of some ecological parameters on the distribution of $m e c A$-positive MRSA strains was observed as a significant correlation between muddy floor and both types of rearing, and also between dry floor and mixed rearing in the milking surrounding environments of both dairy cows and buffalos.

Key words: mecA gene, methicillin-resistance Staphylococcus aureus (MRSA), mecA-positive MRSA, Milk, Mastitis, Air, Soil, Water, Ecological parameters, API ID 32-STAPH, PCR.

\section{INTRODUCTION}

Staphylococcus aureus is a common human pathogen capable of producing a wide range of diseases from skin and soft tissue infections to life-threatening endocarditis, bacteremia and necrotizing pneumonia (Gordon and Lowy, 2008). Infections due to Staph. aureus have assumed new public health importance due to emerging multiple antibiotic resistant strains, particularly methicillin-resistant Staph. aureus (MRSA) and its epidemic clones, increasingly being found in communities and hospitals (Moran et al., 2006; Pesavento et al., 2007; David et al., 2008).

The emergence of pathogenic microorganisms resistant to commonly used antibiotics is a worldwide concern of the $21^{\text {st }}$ century. One of the most important bacteria in this regard is Staph. aureus, in particular its methicillin-resistant strains. The first MRSA strains were isolated from hospitalized patients in the United Kingdom in 1961, i.e. only 2 years after methicillin had started to be used for the treatment of staphylococcal infections (Barber, 1961; Jevons, 1961) and by the mid-1970s had become endemic in many countries (Voss and Doebbeling, 1995).

In the early 1990s, MRSA strains were isolated from the general population in USA (Naimi et al., 2001). However, detection of MRSA in animals, including also the farmed ones, was reported even much earlier in the bovine mastitis literatures, as the first case reported in an animal setting in 1972 following its detection in milk from Belgian dairy cows with 
mastitis (Devriese et al., 1972; Devriese and Hommez, 1975). Recently, there have been several reports of MRSA in both domestic and companion animals including dairy cows in a number of countries worldwide (Lee, 2003; Kaszanyitzky et al., 2004; Kwon et al., 2005; Voss et al., 2005). A comparison of human and farm animal isolates was carried out in some studies, MRSA from infected animals and asymptomatic carriers can be transmitted to humans (Scott et al., 1988; Manian, 2003; Duquette and Nuttall, 2004; Weese et al., 2005; Weese et al., 2006). Some studies strongly suggest that people working with livestock are at a potential risk of becoming MRSA carriers and hence are at an increased risk of infections caused by MRSA (Wulf et al., 2008). Additionally, isolates from cow's milk appeared to be of human origin in a Korean study (Kwon et al., 2005). Transmission of antimicrobial-resistant Staph. aureus strains through foods including milk (da Silva et al., 2004), was involved in human outbreaks has been reported in sporadic cases (EFSA, 2008).

The surrounding environment (air, water, soil...etc) play an important role in transmission of microorganisms. Transmission of MRSA via inanimate objects such as floors, door knobs, switches, tables, etc., within environment has been well documented (Shiomori et al., 2002; Boyce, 2007). These inanimate objects play a role in transmission of disease when MRSA is shed by colonized carriers, or infected individuals, and deposited from direct contact or settled aerosols. In addition, airborne MRSA has been shown to play a significant role in the host-air-surface transmission triangle. For example, MRSA has been shown to not only survive on surfaces for days-to-months, but to maintain the capacity to transmit disease (Boyce et al., 1997; Huang et al., 2006).

The mecA gene is highly conserved in staphylococcal strains and thus is a useful marker of meticillin/oxacillin resistance (Ferreira et al., 2003). Its detection is considered the gold standard for detection of MRSA isolates. The mecA gene is found on a large mobile genetic element called the staphylococcal chromosomal cassette mec (SCCmec) (Van Duijkeren et al., 2004; Weese et al., 2005). However, many laboratories throughout the world do not have the capacity to use molecular techniques to detect MRSA in routine clinical practice. However, such tests may not be widely available outside reference laboratories (Lee et al., 2004; van Duijkeren et al., 2004; CDC, 2005).

The best method for MRSA verification still is PCR, detecting the mecA gene that codes for the resistance determinant. Resistance to methicillin and other $\beta$-lactam antibiotics in MRSA is conferred by the mecA gene, which is part of a 21 to $60-\mathrm{kb}$ mobile genetic element, SCCmec. Expression of mecA yields PBP2a which has a low affinity for $\beta$ - 
lactam rings, the primary active site of $\beta$-lactam antibiotics (Hanssen and Ericson Sollid, 2006).

According to the aforementioned public health hazard and the antimicrobial resistance of MRSA, there is a need to investigate the prevalence of MRSA in the milk of clinically normal and mastitic dairy cattle, in addition to, its incidence in the surrounding milking environment. Also, this study aimed to detect the gene determinant of methicillinresistance (mecA gene) in the isolated MRSA strains as mecA-positive MRSA.

\section{MATERIALS AND METHODS}

\section{- Animal housing:}

This study was conducted in 60 animal houses (30 for dairy cows and 30 for dairy buffalos). Each animal house (of an average area $15 \mathrm{~m}^{2}$ ) was being inside its owner's farmer house (of an average area $135 \mathrm{~m}^{2}$ ) whom distributed in different locations sites in Manfalout city that faraway about $27 \mathrm{~km}$ north of Assiut city. The count of dairy animals was 30 cows as one inside each house; and 38 buffalos as one inside each one of 22 houses and the 8 rest houses had 16 buffalos as 2 for each. Other animal species were found as one donkey, 2-3 sheep and 2-5 goats in each house.

\section{- Sampling:}

A total of 308 samples were taken as 68 milk and 240 environmental samples. Each sample was taken under strictly hygienic conditions and labeled to indicate type, date, time...etc, and then carried with a minimum of delay for bacteriological examination.

\section{I) Milk samples:}

Firstly, the teat apices were cleaned and disinfected with a piece of cotton soaked in $70 \%$ ethyl alcohol, then the first stream of quarter was discarded, and about $20 \mathrm{ml}$ of milk was aseptically drawn from each quarter into a sterile $250 \mathrm{ml}$ capacity glass bottle. Milk sampling was done according to the recommendation of National Mastitis Council (1999).

1. Cows' milk samples: 30 quarter milk samples were taken as one sample from each dairy cow. It was noticed that 5 dairy cows had clinical mastitis.

2. Buffalos' milk samples: 38 quarter milk samples were taken as one sample from each dairy buffalos. It was noticed that 8 dairy buffalos had clinical mastitis.

\section{II) Environmental samples:}


1. Air samples: 60 air samples were collected as one sample from each animal house by means of liquid impinger as described by Cown et al. (1956). $20 \mathrm{ml}$ of sterile normal saline was used for collecting airborne-dust particles. The liquid impinger was adjusted at a rate of $5 \mathrm{~L} / \mathrm{min}$. The amount of air sampled from each house was in ratio to the dimensions of the examined animal enclosure. The air samples were collected at a midday and during the ordinary activity of individuals. During air sampling, liquid impinger was moved inside the house in order to trap all the suspended dust particles to get a representative air samples.

2. Soil samples: 60 soil samples were collected as one sample from each house according to Clegg et al. (1983). Each sample was taken at a depth of $5 \mathrm{~cm}$ from different floor places of the houses and transferred to a clean sterile glass bottle, fitted with sterile ground glass stopper. After thorough mixing of each soil sample, $10 \mathrm{~g}$ was weighted on a sterile glass watch, and then sterile soy broth solution was added and aseptically strained through sterile gauze. The original soil filtrate was collected in a sterile flask for bacteriological examination.

3. Tap water samples: 60 tap water samples were taken as one sample from each house. Each tap water sample was collected in a clean sterile transparent $500 \mathrm{ml}$ capacity glass bottle fitted tightly with ground glass stopper (according the recommendation of WHO, 1971). Before collection of samples, thoroughly cleaning and disinfection of the tap nozzles was done, then water was run for 3-4 min to rinse any accumulated dust and dirt.

4. Pail water samples: 60 pail water samples were taken as one sample from each house in a clean sterile transparent $500 \mathrm{ml}$ capacity glass bottle fitted tightly with ground glass stopper (according the recommendation of WHO, 1971). The bottles were immersed several times in the collected water then filled with water sample.

- Phenotypic identification (Isolation and characterization of Staph. aureus): It was done according to Melter et al. (1999) and Lee (2003). The samples were immediately suspended in Tryptone Soya Broth (TSB, Oxoid) containing $10 \% \mathrm{NaCl}$ and then incubated at $37^{\circ} \mathrm{C}$ for $24 \mathrm{~h}$ for selective enrichment of Staphylococci. Enrichment cultures were then streaked out on Baird-Parker agar and incubated at $35^{\circ} \mathrm{C}$ for 24 to $48 \mathrm{~h}$. The colonies were tested (using conventional methods that included Gram staining, colonial morphology, coagulase test and urease assay) for Staph. aureus levels.

- API ID 32-STAPH: Some positive samples were also re-tested using API ID 32-STAPH (BioMe'rieux, Lyon, France, a commercial identification system for identification of Staphylococci) as confirmatory 
test for Staph. aureus. An API STAPH test strip was done following manufacturer's protocol.

\section{- Phenotypic identification (Isolation and characterization of MRSA):}

The positive samples were re-streaked on mannitol salt agar (MSA, Oxoid) supplemented with $6 \mathrm{mg} / \mathrm{L}$ of oxacillin (Sigma, St. Louis, Mo.) for selective isolation of MRSA. A sample was recorded as positive for MRSA if one or more colonies were identified and one representative colony was chosen from each sample for further testing. MRSA isolates were stored at $-70^{\circ} \mathrm{C}$ in freezer vials pending further PCR assay for the presence of the gene conferring methicillin-resistance ( $m e c A$ gene).

\section{- Preparation of whole-cell DNA extraction for PCR assay:}

The method of Lee (2003) was used for whole-cell DNA extraction. Cells grown in $1.5 \mathrm{ml}$ of Trypticase soy broth at $35^{\circ} \mathrm{C}$ for $20 \mathrm{~h}$ were harvested and centrifuged at $16,000 \times \mathrm{g}$ for $3 \mathrm{~min}$. The pellet was washed with $1.0 \mathrm{ml}$ of sterile distilled water, re-suspended in $50 \mu \mathrm{l}$ of Triton X-100 lysis buffer (100 mM NaCl, $10 \mathrm{mM}$ Tris-HCl [pH 8], $1 \mathrm{mM}$ EDTA [pH 9], $1 \%$ Triton X-100), boiled for $10 \mathrm{~min}$, and then centrifuged at $16,000 \mathrm{x} \mathrm{g}$ for $3 \mathrm{~min}$. The suspension was cooled at room temperature for $5 \mathrm{~min}$ and centrifuged at $16,000 \times \mathrm{g}$ for $3 \mathrm{~min}$. A total of $2 \mathrm{ml}$ of the supernatant was used as the template.

\section{- Genotypic identification (PCR assay for amplification of the mecA gene):}

The presence of the mecA gene was verified for the oxacillinresistant isolates by means of PCR. Amplification of the mecA gene was performed using the primers $m e c A 1$ and mecA2 (Table 1), yielding a PCR product of 533-bp. PCR was performed in a $25 \mu 1$ volume with a PCR buffer containing $10 \mathrm{mM}$ Tris- $\mathrm{HCl}$ [pH 8.3], $50 \mathrm{mM} \mathrm{KCl,} 1.5 \mathrm{mM} \mathrm{MgCl}_{2}$, a $200 \mu \mathrm{M}$ concentration of each deoxynucleoside triphosphate (Promega, Madison, Wisconsin, USA), 2.5 U of Taq polymerase (Promega, Madison, Wisconsin, USA), and a $0.2 \mu \mathrm{M}$ concentration of each primer. Amplification was carried out using 40 cycles of amplification at $94^{\circ} \mathrm{C}$ for $30 \mathrm{~s}, 55^{\circ} \mathrm{C}$ for $30 \mathrm{~s}$, and $72^{\circ} \mathrm{C}$ for $1 \mathrm{~min}$; this reaction was followed by 5 min of an additional extension at $72^{\circ} \mathrm{C}$. PCR products were electrophoresed on a $1.5 \%$ agarose gel. A positive result was inferred by detection of a 533-bp band, which represented a part of the mecA gene.

Table 1. Primers used to type mecA of MRSA isolates.

\begin{tabular}{|c|c|c|c|}
\hline Gene & Primer name & Primer sequence & Reference \\
\hline mecA1 & mecA1 primer & 5'-AAAATCGATGGTAAAGGTTGGC & \multirow{2}{*}{$\begin{array}{l}\text { Murakami } \\
\text { et al. (1991) }\end{array}$} \\
\hline mесA2 & mecA 2 primer & 5'_AGTTCTGCAGTACCGGATTTGC & \\
\hline
\end{tabular}

- Detection of PCR products: 
The amplification products were identified by running $20 \mu \mathrm{l}$ of the PCR reaction mixture in 2\% agrose gel in Tris acid EDATA buffer. Gel was run at $100 \mathrm{~V}$ for $1 \mathrm{~h}$, stained with ethodium bromide solution for 30 min and PCR product bands visualized under UV light. The expected PCR product is 533-bp.

\section{- Ecological parameters:}

Some ecological parameters were recorded during application of the study like rearing of dairy animals (either separate or mixed) and floor (either muddy or dry). After obtaining the results, the distribution of positive samples for $m e c A$-positive MRSA strains were zoned according to the recorded observations.

\section{- Statistical analysis:}

The statistical analysis that represented in the correlation matrix of quantitative data was done with using SPSS version 11.0.

\section{RESULTS}

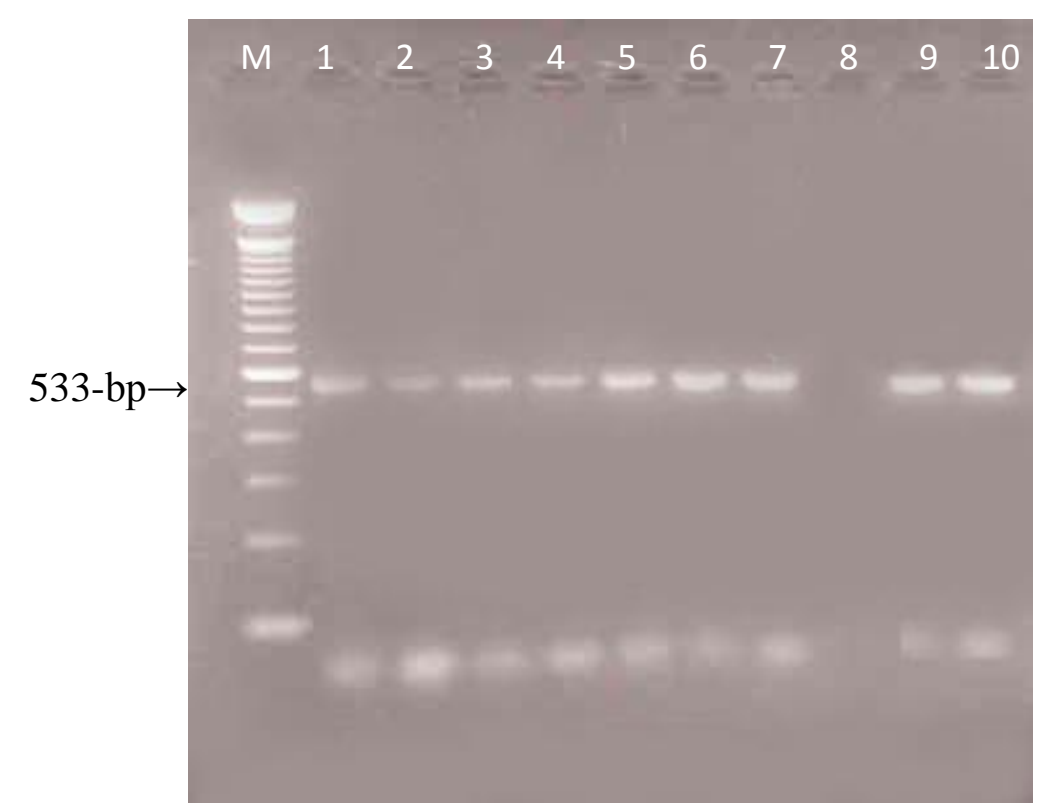

Figure 1. Sensitivity of PCR assay for detection of mecA-positive MRSA strains in the positive samples. $\underline{\mathrm{M}}$ : 100 bp ladder, Lane 1: normal cow's milk, Lane 2: mastitic cow's milk, Lane 3: normal buffalo's milk, Lane 4: mastitic buffalo's milk, Lane 5: air of cows' houses, Lane 6: air of buffalos' houses, Lane 7: soil, Lane 8: tap water (negative), Lane 9: pail water of cows' houses, Lane 10: pail water of buffalos' houses. 


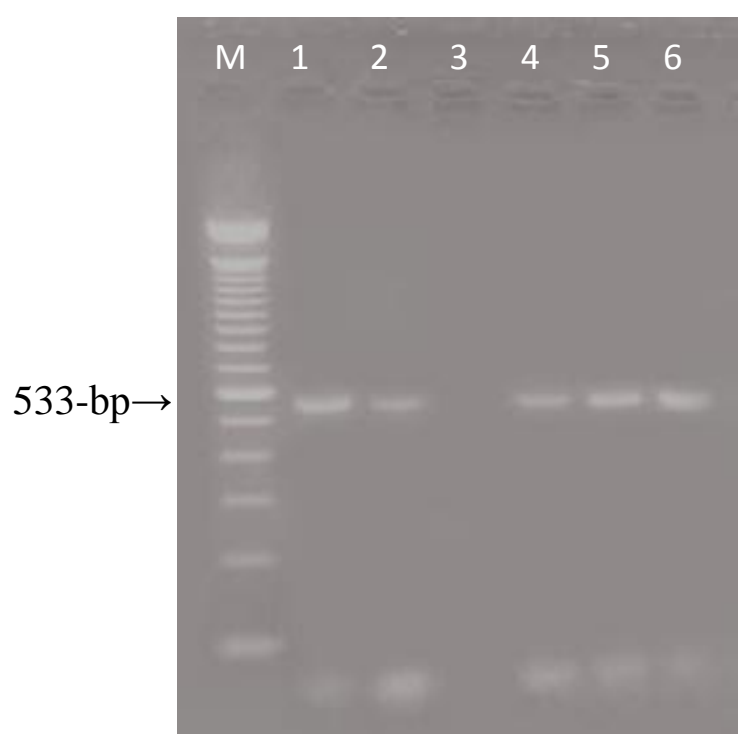

Figure 2. PCR assay showing the only negative samples for mecA gene MRSA in lane 3 (as negative) for tap water samples.

Table 2: Prevalence of positive samples for Staph. aureus, MRSA and $m e c A$-positive MRSA.

\begin{tabular}{|c|c|c|c|c|c|c|c|c|}
\hline \multirow{3}{*}{\multicolumn{2}{|c|}{ Samples }} & \multirow{3}{*}{$\begin{array}{c}\text { Samples } \\
\text { No. }\end{array}$} & \multicolumn{2}{|c|}{ Staph. aureus } & \multicolumn{2}{|c|}{ MRSA } & \multicolumn{2}{|c|}{$\begin{array}{c}m e c A- \\
\text { positive } \\
\text { MRSA }\end{array}$} \\
\hline & & & & & & & & \\
\hline & & & No. & 10 & No. & $\%$ & No. & $\%$ \\
\hline \multirow{2}{*}{$\begin{array}{l}\text { Cows' } \\
\text { milk }\end{array}$} & Normal & 25 & 14 & 56 & 9 & 36 & 5 & 20 \\
\hline & Mastitic & 5 & 5 & 100 & 4 & 80 & 3 & 60 \\
\hline \multirow{2}{*}{$\begin{array}{l}\text { Buffalos' } \\
\text { milk }\end{array}$} & Normal & 30 & 11 & 36.67 & 5 & 16.67 & 3 & 10 \\
\hline & Mastitic & 8 & 5 & 62.5 & 3 & 37.5 & 3 & 37.5 \\
\hline \multirow[b]{2}{*}{ Air } & Cows' houses & 30 & 14 & 46.67 & 8 & 26.67 & 5 & 16.67 \\
\hline & $\begin{array}{c}\text { Buffalos' } \\
\text { houses }\end{array}$ & 30 & 16 & 53.33 & 7 & 23.33 & 3 & 10 \\
\hline \multirow[b]{2}{*}{ Soil } & Cows' houses & 30 & 20 & 66.67 & 10 & 33.33 & 8 & 26.67 \\
\hline & $\begin{array}{c}\text { Buffalos' } \\
\text { houses }\end{array}$ & 30 & 17 & 56.67 & 9 & 30 & 5 & 16.67 \\
\hline \multirow{2}{*}{$\begin{array}{l}\text { Tap } \\
\text { water }\end{array}$} & Cows' houses & 30 & 6 & 20 & 1 & 3.33 & 0 & 0 \\
\hline & Buffalos'houses & 30 & 4 & 13.33 & 1 & 3.33 & 0 & 0 \\
\hline \multirow{3}{*}{$\begin{array}{l}\text { Pail } \\
\text { water }\end{array}$} & Cows' houses & 30 & 13 & 43.33 & 9 & 30 & 8 & 26.67 \\
\hline & Buffalos'houses & 30 & 14 & 46.67 & 9 & 30 & 7 & 23.33 \\
\hline & Total & 308 & 139 & 45.13 & 75 & 24.35 & 50 & 16.23 \\
\hline
\end{tabular}


Table 3: Role of some ecological parameters on the distribution of $m e c A$ positive MRSA.

\begin{tabular}{|c|c|c|c|c|c|}
\hline \multirow{2}{*}{\multicolumn{2}{|c|}{ mecA-positive MRSA }} & \multicolumn{2}{|c|}{ Related communities } & \multicolumn{2}{|c|}{ Management area } \\
\hline & & \multirow{2}{*}{$\begin{array}{c}\begin{array}{c}\text { Separate } \\
\text { rearing }\end{array} \\
3\end{array}$} & \multirow{2}{*}{$\begin{array}{c}\text { Mixed } \\
\text { rearing }\end{array}$} & \multirow{2}{*}{$\begin{array}{c}\begin{array}{c}\text { Muddy } \\
\text { floor }\end{array} \\
3\end{array}$} & \multirow{2}{*}{$\begin{array}{c}\begin{array}{c}\text { Dry } \\
\text { floor }\end{array} \\
2\end{array}$} \\
\hline Cows' & Normal & & & & \\
\hline Milk & Mastitic & 2 & 1 & 2 & 1 \\
\hline \multirow{2}{*}{$\begin{array}{l}\text { Buffalos' } \\
\text { Milk }\end{array}$} & Normal & 2 & 1 & 2 & 1 \\
\hline & Mastitic & 1 & 2 & 1 & 2 \\
\hline \multirow{2}{*}{ Air } & Cows' houses & 2 & 3 & 2 & 3 \\
\hline & Buffalos' houses & 1 & 2 & 2 & 1 \\
\hline \multirow{2}{*}{ Soil } & Cows' houses & 3 & 5 & 5 & 3 \\
\hline & Buffalos' houses & 2 & 3 & 3 & 2 \\
\hline \multirow{2}{*}{$\begin{array}{l}\text { Tap } \\
\text { Water }\end{array}$} & Cows' houses & 0 & 0 & 0 & 0 \\
\hline & Buffalos' houses & 0 & 0 & 0 & 0 \\
\hline \multirow{2}{*}{$\begin{array}{l}\text { Pail } \\
\text { Water }\end{array}$} & Cows' houses & 3 & 5 & 6 & 2 \\
\hline & Buffalos' houses & 3 & 4 & 4 & 3 \\
\hline \multirow{2}{*}{\multicolumn{2}{|c|}{ Total }} & 22 & 28 & 30 & 20 \\
\hline & & \multicolumn{2}{|c|}{50} & \multicolumn{2}{|c|}{50} \\
\hline
\end{tabular}

Table 4: Some recorded studies about incidence of the isolated strains.

\begin{tabular}{|c|c|c|c|c|c|c|c|c|c|}
\hline \multirow{2}{*}{ Samples } & \multicolumn{3}{|c|}{ Staph. aureus } & \multicolumn{3}{|c|}{ MRSA } & \multicolumn{3}{|c|}{ mecA-positive MRSA } \\
\hline & $\%$ & Country & Reference & $\%$ & Country & Reference & $\%$ & Country & Reference \\
\hline \multirow{4}{*}{$\begin{array}{l}\text { Normal } \\
\text { milk }\end{array}$} & 28.93 & Korea & Lee (2003) & 0.9 & Korea & $\begin{array}{c}\text { Lee } \\
(2003)\end{array}$ & 0.34 & Korea & $\begin{array}{c}\text { Lee } \\
(2003) \\
\end{array}$ \\
\hline & 15.9 & $\begin{array}{l}\text { Czech } \\
\text { Republic }\end{array}$ & $\begin{array}{c}\text { Zouharova } \\
\text { and } \\
\text { Rysanek } \\
(2008) \\
\end{array}$ & 0 & Switzerland & $\begin{array}{l}\text { Huber } \\
\text { et al. } \\
(2010)\end{array}$ & - & - & - \\
\hline & 22.22 & $\begin{array}{l}\text { Czech } \\
\text { Republic }\end{array}$ & $\begin{array}{c}\text { Stastkova } \\
\text { et al. } \\
(2009) \\
\end{array}$ & 3.27 & $\begin{array}{c}\text { Czech } \\
\text { Republic }\end{array}$ & $\begin{array}{c}\text { Stastkova } \\
\text { et al. } \\
(2009) \\
\end{array}$ & - & - & - \\
\hline & 45.45 & Egypt & $\begin{array}{c}\text { Present } \\
\text { study }\end{array}$ & 25.45 & Egypt & $\begin{array}{c}\text { Present } \\
\text { study }\end{array}$ & 14.55 & Egypt & $\begin{array}{c}\text { Present } \\
\text { study }\end{array}$ \\
\hline \multirow{4}{*}{$\begin{array}{l}\text { Mastitic } \\
\text { milk }\end{array}$} & 33.79 & Egypt & $\begin{array}{c}\text { Mokhbatly } \\
\text { et al. } \\
\text { (2001) }\end{array}$ & 13.73 & Korea & $\begin{array}{l}\text { Moon } \\
\text { et al. } \\
\text { (2007) } \\
\end{array}$ & - & - & - \\
\hline & 40.5 & Ethiopia & $\begin{array}{l}\text { Workinen } \\
\text { et al. } \\
(2002) \\
\end{array}$ & 5.56 & Portugal & $\begin{array}{c}\text { Pereira } \\
\text { et al. } \\
(2009) \\
\end{array}$ & - & - & - \\
\hline & 100 & Switzerland & $\begin{array}{l}\text { Huber } \\
\text { et al. } \\
\text { (2010) }\end{array}$ & 1.41 & Switzerland & $\begin{array}{l}\text { Huber } \\
\text { et al. } \\
\text { (2010) }\end{array}$ & - & - & - \\
\hline & 76.92 & Egypt & $\begin{array}{c}\text { Present } \\
\text { study }\end{array}$ & 53.85 & Egypt & $\begin{array}{c}\text { Present } \\
\text { study }\end{array}$ & 46.15 & Egypt & $\begin{array}{c}\text { Present } \\
\text { study }\end{array}$ \\
\hline \multirow{2}{*}{$\begin{array}{l}\text { Enviro- } \\
\text { nmental }\end{array}$} & 0 & $\begin{array}{c}\text { Czech } \\
\text { Republic }\end{array}$ & $\begin{array}{c}\text { Stastkova } \\
\text { et al. } \\
(2009) \\
\end{array}$ & 0 & $\begin{array}{c}\text { Czech } \\
\text { Republic }\end{array}$ & $\begin{array}{c}\text { Stastkova } \\
\text { et al. } \\
(2009) \\
\end{array}$ & 0 & $\begin{array}{l}\text { Czech } \\
\text { Republic }\end{array}$ & $\begin{array}{l}\text { Stastkova } \\
\text { et al. } \\
\text { (2009) }\end{array}$ \\
\hline & 43.33 & Egypt & $\begin{array}{c}\text { Present } \\
\text { study }\end{array}$ & 22.5 & Egypt & $\begin{array}{c}\text { Present } \\
\text { study }\end{array}$ & 15 & Egypt & $\begin{array}{c}\text { Present } \\
\text { study }\end{array}$ \\
\hline
\end{tabular}


Table 5: Correlation matrix among the isolated strains in milking surrounding environment of dairy cows.

\begin{tabular}{|l|c|c|c|}
\hline \multicolumn{1}{|c|}{ Cows' environment } & Staph. aureus & MRSA & mecA-positive MRSA \\
\hline Staph. aureus & 1.000 & & \\
\hline MRSA & $0.886^{*}$ & 1.000 & \\
\hline mecA-positive MRSA & 0.754 & $0.812^{*}$ & 1.000 \\
\hline
\end{tabular}

**Correlation is significant at the 0.01 level (2-tailed).

*Correlation is significant at the 0.05 level (2-tailed).

Table 6: Correlation matrix among the examined samples in milking surrounding environment of dairy cows.

\begin{tabular}{|l|c|c|c|c|c|c|}
\hline $\begin{array}{c}\text { Cows' } \\
\text { environment }\end{array}$ & $\begin{array}{c}\text { Normal } \\
\text { milk }\end{array}$ & $\begin{array}{c}\text { Mastitic } \\
\text { milk }\end{array}$ & Air & Soil & $\begin{array}{c}\text { Tap } \\
\text { water }\end{array}$ & $\begin{array}{c}\text { Pail } \\
\text { water }\end{array}$ \\
\hline Normal milk & 1.000 & & & & & \\
\hline Mastitic milk & $0.998^{*}$ & 1.000 & & & & \\
\hline Air & 0.992 & 0.982 & 1.000 & & & \\
\hline Soil & 0.954 & 0.933 & 0.984 & 1.000 & & \\
\hline Tap water & 0.954 & 0.933 & 0.984 & $1.000^{* *}$ & 1.000 & \\
\hline Pail water & 0.964 & 0.945 & 0.990 & $0.999^{*}$ & $0.999^{*}$ & 1.000 \\
\hline
\end{tabular}

**Correlation is significant at the 0.01 level (2-tailed).

*Correlation is significant at the 0.05 level (2-tailed).

Table 7: Correlation matrix of some ecological parameters in milking surrounding environment of dairy cows.

\begin{tabular}{|l|c|c|c|c|}
\hline \multicolumn{1}{|c|}{$\begin{array}{c}\text { Cows' } \\
\text { environment }\end{array}$} & $\begin{array}{c}\text { Separate } \\
\text { rearing }\end{array}$ & $\begin{array}{c}\text { Mixed } \\
\text { rearing }\end{array}$ & $\begin{array}{c}\text { Muddy } \\
\text { floor }\end{array}$ & $\begin{array}{c}\text { Dry } \\
\text { floor }\end{array}$ \\
\hline Separate rearing & 1.000 & & & \\
\hline Mixed rearing & 0.725 & 1.000 & & \\
\hline Muddy floor & $0.886^{*}$ & $0.786^{*}$ & 1.000 & \\
\hline Dry floor & 0.502 & $0.741^{*}$ & 0.445 & 1.000 \\
\hline
\end{tabular}

**Correlation is significant at the 0.01 level (2-tailed).

*Correlation is significant at the 0.05 level (2-tailed).

Table 8: Correlation matrix among the isolated strains in milking surrounding environment of dairy buffalos.

\begin{tabular}{|l|c|c|c|}
\hline Buffalos' environment & Staph. aureus & MRSA & mecA-positive MRSA \\
\hline Staph. aureus & 1.000 & & \\
\hline MRSA & $0.899^{*}$ & 1.000 & \\
\hline mecA-positive MRSA & 0.783 & $0.971^{* *}$ & 1.000 \\
\hline
\end{tabular}

**Correlation is significant at the 0.01 level (2-tailed).

*Correlation is significant at the 0.05 level (2-tailed). 
Table 9: Correlation matrix among the examined samples in milking surrounding environment of dairy buffalos.

\begin{tabular}{|l|c|c|c|c|c|c|}
\hline $\begin{array}{c}\text { Buffalos' } \\
\text { environment }\end{array}$ & $\begin{array}{c}\text { Normal } \\
\text { milk }\end{array}$ & $\begin{array}{c}\text { Mastitic } \\
\text { milk }\end{array}$ & Air & Soil & $\begin{array}{c}\text { Tap } \\
\text { water }\end{array}$ & $\begin{array}{c}\text { Pail } \\
\text { water }\end{array}$ \\
\hline Normal milk & 1.000 & & & & & \\
\hline Mastitic milk & 0.971 & 1.000 & & & & \\
\hline Air & $0.998^{*}$ & 0.954 & 1.000 & & & \\
\hline Soil & 0.996 & 0.945 & $1.000^{*}$ & 1.000 & & \\
\hline Tap water & $1.000^{*}$ & 0.971 & $0.998^{*}$ & 0.996 & 1.000 & \\
\hline Pail water & $0.999^{*}$ & 0.961 & $1.000^{*}$ & $0.999^{*}$ & $0.999^{*}$ & 1.000 \\
\hline
\end{tabular}

**Correlation is significant at the 0.01 level (2-tailed).

*Correlation is significant at the 0.05 level (2-tailed).

Table 10: Correlation matrix of some ecological parameters in milking surrounding environment of dairy Buffalos.

\begin{tabular}{|l|c|c|c|c|}
\hline \multicolumn{1}{|c|}{$\begin{array}{c}\text { Buffalos' } \\
\text { environment }\end{array}$} & $\begin{array}{c}\text { Separate } \\
\text { rearing }\end{array}$ & $\begin{array}{c}\text { Mixed } \\
\text { rearing }\end{array}$ & $\begin{array}{c}\text { Muddy } \\
\text { floor }\end{array}$ & $\begin{array}{c}\text { Dry } \\
\text { floor }\end{array}$ \\
\hline Separate rearing & 1.000 & & & \\
\hline Mixed rearing & 0.667 & 1.000 & & \\
\hline Muddy floor & $0.889^{*}$ & $0.786^{*}$ & 1.000 & \\
\hline Dry floor & 0.692 & $0.889^{*}$ & 0.667 & 1.000 \\
\hline
\end{tabular}

**Correlation is significant at the 0.01 level (2-tailed).

*Correlation is significant at the 0.05 level (2-tailed).

\section{DISCUSSION}

It is obvious from the aforementioned results in Table 2 that, all the examined samples contained Staph. aureus with incidence in mastitic cows' milk as $100 \%$. It was hypothesized that Staph. aureus would be isolated from milk samples but the prevalence of MRSA would be low (Table 4), in agreement with Lee (2003); Stastkova et al. (2009); Virgin et al. (2009); Huber et al. (2010). Additionally, It was noticed that the prevalence of MRSA became lower than Staph. aureus not only in the examined milk samples but also in the surrounding environmental samples, with accordance to Stastkova et al. (2009).

Why the design study interested with the surrounding milking environment besides milk? The answer summarized in the fact that air and soil in the stables can play an important role in the spread of MRSA to the environment (Dewaele et al., 2008). As Staph. aureus is present in soil, water sources and air (Hamann, 1986) and the prevalence of MRSA in 
animals' environment continues to rise, there is an inherent risk for new MRSA clones to evolve secondary to horizontal gene transfer and host selection pressure and then spread to human hosts (Lin et al., 2010). Thus, the presence of MRSA in animals is a concern not limited only to veterinarians and animal health care workers, but to the public health at large (Lin et al., 2010).

Here, accuracy and promptness in the detection of MRSA are of key importance in ensuring the correct antibiotic treatment in mastitic animals and control their spreading to the environment (Velasco et al., 2005). MRSA strains were isolated from mastitic milk in approximately double percentages more than normal milk (Table 2). MRSA has been detected in the milk of cows with mastitis in many studies (Lee, 2003; Leonard and Markey, 2006). Middleton et al. (2005) found all MRSA strains isolated from bovine species were from milk samples. Moreover, none of the MRSA isolates was recovered from environmental samples in the study of Stastkova et al. (2009).

Key question investigated is, why this study deals deeply with mecA gene-positive MRSA rather than just MRSA detection? Because mecA gene encodes resistance to methicillin (Bosgelmez-Tinaz et al., 2006); i.e. the definition of Staph. aureus isolates with phenotypic methicillin-resistance as MRSA requires demonstration of the mecA gene. The gene mecA has been reported to be responsible for methicillinresistance (Zhang et al., 2004; Bagcigil et al., 2007; Zaraket et al., 2007; Zhang et al., 2008) that was determined during the genotypic identification step. If expressed, this gene confers resistance to all penicillins and cephalosporins (Brakstad and Maeland, 1997). The role of inappropriate antibiotic usage in the spread of antimicrobial resistance must also be considered. Exposure to broad spectrum antibiosis (notably $3^{\text {rd }}$ generation cephalosporins and fluoroquinolones) has been associated with an increased risk of MRSA infection in several studies (Campillo et al., 2002; Hori et al., 2002).

The used PCR assay showed the sensitivity for detection of mecApositive MRSA in the positive samples of clinically normal and mastitic milk, air, soil and pail water. While, tap water was found free from mecApositive MRSA as shown in PCR gel photo as negative band of lane 8 (Figure 1) and of lane 3 (Figure 2).

The incidence of $m e c A$-positive MRSA among the examined clinically mastitic milk (Table 2), emphasized the importance of detection of mecA gene in the isolated MRSA strains in order to ensure the appropriate antimicrobial chemotherapy of staphylococcal infections, particularly those from community associated infections (Palavecino, 2004; 
Kazakova et al., 2005). In a Korean dairy farms with livestock with mastitis problems, antibiotics (including members of the penicillin family such as ampicillin and penicillin) are largely used as a dry-cow treatment, although oxacillin and methicillin are rarely used in this veterinary field; this practice may contribute to increase incidence of MRSA strains in cows associated with mastitis (Lee, 2003).

It is clear from Table 2 that, the incidence of mecA-positive MRSA in mastitic milk was higher than clinically normal ones in both of cows' and buffalos' milk samples. Similarly, Lee (2003) found the all 12 mecApositive MRSA isolates delivered from cattle specimens were originated from milk samples and 9 of them were from mastitic milk.

The correlation among the isolated strains in the milking surrounding environment of dairy cows was statistically analyzed in Table 5, showing a significant correlation (at 0.05 level) between Staph. aureus and MRSA and between MRSA and $m e c A$-positive MRSA. A significant correlation between milk samples of cows' milk was observed, in addition to a highly significant correlation between soil and water (Table 6). Also for the cows' environment, mecA-positive MRSA strains were found distributed ecologically in muddy floor in a significant correlation with separate and mixed rearing with neighboring farm animals, and also between dry floor and mixed rearing (Table 7).

With forward to the buffalos' environment, a high significant correlation (at 0.01 level) between MRSA and mecA-positive MRSA was recorded in Table 8, with possible contamination from air and water to milk samples as seen in the significant correlation between milk and air and water in Table 9. The significant correlation of ecological distribution of mecA-positive MRSA strains in the buffalos' environment looked like of the cows' environment (Table 10); concluding the role of dry floor incorporated with separate rearing in reducing the contamination to milk and considered as one of the good management.

MRSA may be present in milk as a result of contamination from udder or other environmental sources (air, soil, water). The significantly positive correlation between mecA-positive MRSA in milk and animal environment may be attributed to the high microbial contamination in dairy houses due to the long time spend by animals inside them (Schreinger and ruegg, 2003).

Regular audit of environmental cleaning should be carried out (Dancer, 2004). Otherwise, Lloyd et al. (2007) stated key points on dealing with MRSA in companion animal practice: 1) MRSA is prevalent in humans and animals and in their environment, 2) veterinary staff may be predisposed to MRSA carriage, 3) transfer of MRSA between people and 
animals can occur in both directions, 4) MRSA infection in animals usually has a good prognosis, 5) rigorous infection control policies and diligent hand washing can greatly reduce the spread of MRSA.

In conclusion, milk, air, soil and water from the milking environment of both dairy cows and buffalos were found contaminated with Staph. aureus, MRSA and mecA-positive MRSA strains with high incidences in the clinically mastitic milk of both dairy cows and buffalos. Significant correlations were observed between samples with highlighting the focus towards the possible contamination from environment into milk especially in the muddy floor incorporated with mixed rearing for both dairy cows and dairy buffalos.

\section{REFERENCES}

Bagcigil, F.A.; Moodley, A.; Baptiste, K.E.; Jensen, V.F. and Guardabassi, L. (2007): Occurrence, species distribution, antimicrobial resistance and clonality of methicillin- and erythromycin-resistant Staphylococci in the nasal cavity of domestic animals. Vet. Microbiol. 121:307-315.

Barber, M. (1961): Methicillin-resistant Staphylococci. J. Clin. Pathol. 14:385-393.

Bosgelmez-Tinaz, G.; Ulusoy, S.; Aridođan B. and Coskun-Ari, F. (2006): Evaluation of different methods to detect oxacillin resistance in Staphylococcus aureus and their clinical laboratory utility. Europ. J. Clin. Microbiol. Infect. Dis. 25:410-412.

Boyce, J.M. (2007): Environmental contamination makes an important contribution to hospital infection. J. Hosp. Infect. 65(2):50-54.

Boyce, J.M.; Potter-Bynoe, G.; Chenevert, C. and King, T. (1997): Environmental contamination due to methicillin-resistant Staphylococcus aureus: Possible infection control implications. Infection Control Hospital Epi. 18:622-627.

Brakstad, O.G. and Maeland, J.A. (1997): Mechanisms of methicillin resistance in Staphylococci. Apmis, 105:264-276.

Campillo, B.; Richardet, J.P.; Kheo, T. and Dupeyron, C. (2002): Nosocomial spontaneous bacterial peritonitis and bacteremia in cirrhotic patients: impact of isolate type on prognosis and characteristics of infection. Clin. Infect. Dis. 35:1-10.

CDC (Centers for Disease Control and Prevention) (2005): Healthcareassociated methicillin resistant Staphylococcus aureus (HAMRSA).Available http://www.cdc.gov/ncidod/dhqp/ar_mrsa.html. Accessed 17 Apr 2006. 
Clegg, F.G.; Chiejina, S.N.; Duncan, A.L.; Kay, R.N. and Wray, C. (1983): Outbreak of Salmonella Newport infection in dairy herds and their relationship to management and contamination of the environment. Vet. Rec. 112.

Cown, W.B.; Kethley, T.W. and Fincher, E.L. (1956): The critical orifice liquid impinger as sampler for bacteriological aerosols. J. Appl. Microbiol. 5:119-124.

da Silva, E.R.; Sigueira, A.P.; Martins, J.C.D.; Ferreria, W.P.B. and da Silva, N. (2004): Identification and in vitro antimicrobial susceptibility of Staphylococcus species isolated from goat mastitis in the Northeast of Brazil. Small Ruminant Res. 55:4549.

Dancer, S.J. (2004): How do we assess hospital cleaning? A proposal for microbiological standards for surface hygiene in hospitals. J. Hosp. Infect. 56:10-15.

David, M.Z.; Glikman, D.; Crawford, S.E.; Peng, J.; King, K.J.; Hostetler, M.A.; Boyle-Vavra, S. and Daum, R.S. (2008): What is community-associated methicillin-resistant Staphylococcus aureus? J. Infect. Dis. 197:1235-1243.

Devriese, L.A. and Hommez, J. (1975): Epidemiology of methicillinresistant Staphylococcus aureus in dairy herds. Res. Vet. Sci. 19:23-27.

Devriese, L.A.; Van Damme, L.R. and Fameree, L. (1972): Methicillin (cloxacillin)-resistant Staphylococcus aureus strains isolated from bovine mastitis cases. J. Vet. Med. B, Infectious Diseases and Veterinary Public Health, 19:598-605.

Dewaele, I.; De Man, I.; Stael, A.; Delputte, P.; Butaye, P.; Vlaemynck, G.; Herman, L.; Heyndrickx, M. and Rasschaert, G. (2008): Methicillin-resistant Staphylococcus aureus (MRSA) on Belgian pig farms. ILVO - Technologie en Voeding http://www.ilvo.vlaanderen.be/T\&V.

Duquette, R.A. and Nuttall, T.J. (2004): Methicillin-resistant Staphylococcus aureus in dogs and cats: an emerging problem? J. Small Anim. Pract. 45(12):591-597.

EFSA (European Food Safety Authority) (2008): Foodborne antimicrobial resistance as a biological hazard. Scientific Opinion of the Panel on Biological Hazards (Question No EFSA-Q-2007-089).

Ferreira, R.B.; Iorio, N.L.; Malvar, K.L.; Nunes, A.P.; Fonseca, L.S.; Bastos, C.C. and Santos, K.R. (2003): Coagulase-negative Staphylococci: comparison of phenotypic and genotypic oxacillin susceptibility tests and evaluation of the agar-screening test by 
using different concentrations of oxacillin. J. Clin. Microbiol. 41: 3609-3614.

Gordon, R.J. and Lowy, F.D. (2008): Pathogenesis of methicillin-resistant Staphylococcus aureus infection. Clin. Infect. Dis. 46 Suppl. 5:S350-S359.

Hamann, J.Z. (1986): Treansfer von Mastitiserregen in abhangigkeit vom Merlksytem. Milchwissenchaft, 37:283-286.

Hanssen, A.M. and Ericson Sollid, J.U. (2006): SCCmec in Staphylococci: genes on the move. FEMS Immunol. Med. Microbiol. 46:8-20.

Hori, S.; Sunley, R.; Tami, A. and Grundmann, H. (2002): The Nottingham Staphylococcus aureus population study: prevalence of MRSA among the elderly in a university hospital. J. Hosp. Infect. 50:2529.

Huang, R.; Mehta, S.; Weed, D. and Savor Price, C. (2006): Methicillinresistant Staphylococcus aureus Survival on hospital fomites. Infection Control Hospital Epi. 27(11):1267-1269.

Huber, H.; Koller, S.; Giezendanner, N.; Stephan, R. and Zweifel, C. (2010): Prevalence and characteristics of meticillin-resistant Staphylococcus aureus in humans in contact with farm animals, in livestock, and in food of animal origin, Switzerland, 2009. Euro Surveill. 15(16): pii=19542. Available online: http:// www.eurosurveillance.org/ViewArticle.aspx?ArticleId=19542.

Jevons, M.P. (1961): Celbenin-resistant Staphylococci. British Med. J. $1: 24-25$.

Kaszanyitzky, E.J.; Egyed, Z.; Janosi, S.; Keseru, J.; Gal, Z.; Szabo, I.; Veres, Z. and Somogyi, P. (2004): Staphylococci isolated from animals and food with phenotypically reduced susceptibility to betalactamase-resistant beta-lactam antibiotics. Acta Vet. Hung. 52(1):7-17.

Kazakova, S.V.; Hageman, J.C.; Matava, M.; Srinivasan, A.; Phelan, L.; Garfinkel, B.; Boo, T.; McAllister, S.; Anderson, J.; Jensen, B.; Dodson, D.; Lonsway, D.; McDougal, L.K.; Arduino, M.; Fraser, V.J.; Killgore, G.; Tenover, F.C.; Cody, S. and Jernigan, D.B. (2005): A clone of methicillin-resistant Staphylococcus aureus among professional football players. N. Engl. J. Med. 352:468475.

Kwon, N.H.; Park, K.T.; Moon, J.S.; Jung, W.K.; Kim, S.H.; Kim, J.M.; Hong, S.K.; Koo, H.C.; Joo, Y.S. and Park, Y.H. (2005): Staphylococcal cassette chromosome mec (SCCmec) characterization and molecular analysis for methicillin-resistant Staphylococcus aureus and novel SCCmec subtype IVg isolated 
from bovine milk in Korea. J. Antimicrob. Chemother. 56:624632.

Lee, J.H. (2003): Methicillin (oxacillin)-resistant Staphylococcus aureus strains isolated from major food animals and their potential transmission to humans. Appl. Environ. Microbiol. 69 (11):64896494.

Lee, J.H.; Jeong, J.M.; Park, Y.H.; Choi, S.S.; Kim, Y.H.; Chae, J.S.; Moon, J.S.; Park, H.; Kim, S. and Eo, S.K. (2004): Evaluation of the methicillin-resistant Staphylococcus aureus (MRSA)-Screen latex agglutination test for detection of MRSA of animal origin. J. Clin. Microbiol. 42(6):2780-2782.

Leonard, F.C. and Markey, B.K. (2006): Methicillin-resistant Staphylococcus aureus in animals: A review. Vet. J. 175:17-36.

Lin, Y.; Barker, E.; Kislow, J.; Kaldhone, P.; Stemper, M.E.; Pantrangi, M.; Moore, F.M.; Hall, M.; Fritsche, T.R.; Novicki, T.; Foley, S.L. and Shukla, S.K. (2010): Evidence of multiple virulence subtypes in nosocomial and community-associated MRSA genotypes in companion animals from the upper Midwestern and northeastern United States. Marshfield Clinic, CM\&R Rapid Release, Published online ahead of print September 2, 2010 as doi:10.3121/cmr.2010.944.

Lloyd, D.H.; Boag, A.K. and Loeffler, A. (2007): Dealing with MRSA in companion animal practice. EJCAP, 17 (1):85-93.

Manian, F.A. (2003): Asymptomatic nasal carriage of mupirocin-resistant, methicillin-resistant Staphylococcus aureus (MRSA) in a pet dog associated with MRSA infection in household contacts. Clin. Infect. Dis. 36(2):e26-28.

Melter, O.; Santos Sanches, I.; Schindler, J.; Aires de Sousa, M.; Mato, R.; Kovarova, V.; Zemlickova, H. and de Lencastre, H. (1999): Methicillin-resistant Staphylococcus aureus clonal types in the Czech Republic. J. Clin. Microbiol. 37:2798-2803.

Middleton, J.R.; Fales, W.H.; Luby, C.D.; Oaks, J.L.; Sanchez, S.; Kinyon, J.M.; Wu, C.C.; Maddox, C.W.; Welsh, R.D. and Hartmann, F. (2005): Surveillance of Staphylococcus aureus in Veterinary Teaching Hospitals. J. Clin. Microbiol. 43(6):2916-2919.

Mokhbatly, A.A.; Desouky, M.I.; El-Sawak, M.I. and Abou El-Azb, M.F. (2001): Clinicopathological studies on subclinical mastitis in cattle and buffaloes in Kafr El-Sheikh governorate. Suez Canal Vet. Med. J. 4(1): 123-135.

Moon, J.S.; Lee, A.H.; Kang, H.M.; Lee, E.S.; Kim, M.N.; Paik, Y.H.; Park, Y.H.; Joo, Y.S. and Koo, H.C. (2007): Phenotypic and 
genetic antibiogram of methicillin-resistant Staphylococci isolated from bovine mastitis in Korea. J. Dairy Sci. 90:1176-1185.

Moran, G.J.; Krishnadasan, A.; Gorwitz, R.J.; Fosheim, G.E.; McDougal, L.K.; Carey, R.; Talan, D.A.; Emergency ID NET Study Group (2006): Methicillin-resistant $S$. aureus infections in the emergency department. N. Engl. J. Med. 355:666-674.

Murakami, K.; Minamide, W.; Wada, K.; Nakamura, E.; Teraoka, H. and Watanabe, S. (1991): Identification of methicillin-resistant strains of Staphylococci by polymerase chain reaction. J. Clin. Microbiol. 29 (10):2240-2244.

Naimi, T.S.; LeDell, K.H.; Boxrud, D.J.; Groom, A.V.; Steward, C.D.; Johnson, S.K.; Besser, J.M.; O'Boyle, C.; Danila, R.N.; Cheek, J.E.; Osterholm, M.T.; Moore, K.A. and Smith, K.E. (2001): Epidemiology and clonality of community-acquired methicillinresistant Staphylococcus aureus in Minnesota, 1996-1998. Clin. Infect. Dis. 33:990-996.

National Mastitis Council (1999): Laboratory handbook on bovine mastitis. National Mastitis Council, Madison, WI.

Palavecino, E. (2004): Community-acquired methicillin-resistant Staphylococcus aureus infections. Clin. Lab. Med. 24:403-418.

Pereira, V.; Lopes, C.; Castro, A.; Silva, J.; Gibbs, P. and Teixeira, P. (2009): Characterization for enterotoxin production, virulence factors, and antibiotic susceptibility of Staphylococcus aureus isolates from various foods in Portugal. European Economic Community IP016264-2 project "TRUE FOOD, Traditional United Europe Food'’.

Pesavento, G.; Ducci, B.; Comodo, N. and Nostro, A.L. (2007): Antimicrobial resistance profile of Staphylococcus aureus isolated from raw meat: a research for methicillin-resistant Staphylococcus aureus (MRSA). Food Control, 18:196-200.

Schreinger, D.A. and ruegg, P.L. (2003): Relationship between udder and leg hygiene scores and subclinical mastitis. J. Dairy Sci. 86:34603465.

Scott, G.M.; Thomson, R.; Malone-Lee, J. and Ridgway, G.L. (1988): Cross-infection between animals and man: possible feline transmission of Staphylococcus aureus infection in humans? J. Hosp. Infect. 12:29-34.

Shiomori, T; Miyamoto, H.; Makishima, K.; et al. (2002): Evaluation of bedmaking-related airborne and surface methicillin-resistant Staphylococcus aureus contamination. J. Hosp. Infect. 50:30-35. 
Stastkova, Z.; Karpiskova, S. and Karpiskova, R. (2009): Occurrence of methicillin-resistant strains of Staphylococcus aureus at a goat breeding farm. Veterinarni Medicina, 54 (9):419-426.

van Duijkeren, E.; Wolfhagen, M.J.; Box, A.T.; Heck, M.E.; Wannet, W.J. and Fluit, A.C. (2004): Human-to-dog transmission of methicillinresistant Staphylococcus aureus. Emerg. Infect. Dis. 10(12):22352237.

Velasco, D.; del Mar Tomas, M.; Cartelle, M.; Beceiro, A.; Perez, A.; Molina, F.; Moure, R.; Villanueva, R. and Bou, G. (2005): Evaluation of different methods for detecting methicillin (oxacillin) resistance in Staphylococcus aureus. J. Antimicrob. Chemother. 55:379-382.

Virgin, J.E.; van Slyke, T.M.; Lombard, J.E. and Zadoks, R.N. (2009): Methicillin-resistant Staphylococcus aureus detection in US bulk tank milk. J. Dairy Sci. 92(10):4988-4991.

Voss, A. and Doebbeling, B.N. (1995): The worldwide prevalence of methicillin-resistant Staphylococcus aureus. Int. J. Antimicrob. Agents, 5:101-106.

Voss, A.; Loeffen, F.; Bakker, J.; Klaasen C. and Wulf, M. (2005): Methicillin-resistant Staphylococcus aureus in pig farming. Emerg. Infect. Dis. 11:1965-1966.

Weese, J.S.; Archambault, M.; Willey, B.M.; Hearn, P.; Kreiswirth, B.N.; Said-Salim, B.; McGeer, A.; Likhoshvay, Y.; Prescott, J.F. and Low, D.E. (2005): Methicillin-resistant Staphylococcus aureus in horses and horse personnel, 2000-2002. Emerg. Infect. Dis. (3):430-435.

Weese, J.S.; Caldwell, F.; Willey, B.M.; Kreiswirth, B.N.; McGeer, A.; Rousseau, J. and Low, D.E. (2006): An outbreak of methicillinresistant Staphylococcus aureus skin infections resulting from horse to human transmission in a veterinary hospital. Vet. Microbiol. 114(1-2):160-164.

WHO, (1971): International standards for drinking water. Plais de Nation, $3^{\text {rd }}$ Ed. Geneva.

Workinen, S.; Bayleyegn, M. Mekonnen, H. and Potgieter, L.N.D. (2002): Prevalence and etiology of mastitis in cow from two major Ethiopian dairies. Trop. Anim. Health Prod. 34(1):19-25.

Wulf, M.W.; Sørum, M.; van Nes, A.; Skov, R.; Melcher, W.J.G.; Klaassen, C.H.W. and Voss, A. (2008): Prevalence of methicillin-resistant Staphylococcus aureus among veterinarians: an international study. Clin. Microbiol. Infect. 14(1):29-34. 
Zaraket, H.; Otsuka, T.; Saito, K.; Dohmae, S.; Takano, T.; Higuchi, W.; Ohkubo, T.; Ozaki, K.; Takano, M.; Reva, I.; Baranovich, T. and Yamamoto, T. (2007): Molecular characterization of methicillinresistant Staphylococcus aureus in hospitals in Niigata, Japan: divergence and transmission. Microbiol. Immunol. 51:171-176.

Zhang, K.; McClure, J.; Elsayed, S.; Louie, T. and Conly, J.M. (2008): Novel multiplex PCR assay for simultaneous identification of community-associated methicillin-resistant Staphylococcus aureus strains USA300 and USA400 and detection of mecA and PantonValentine leukocidin genes, with discrimination of Staphylococcus aureus from coagulase-negative Staphylococci. J. Clin. Microbiol. 46:1118-1122.

Zhang, K.; Sparling, J.; Chow, B.L.; Elsayed, S.; Hussain, Z.; Church, D.L.; Gregson, D.B.; Louie, T. and Conly, J.M. (2004): New quadriplex PCR assay for detection of methicillin and mupirocin resistance and simultaneous discrimination of Staphylococcus aureus from coagulase-negative Staphylococci. J. Clin. Microbiol. 42:4947-4955.

Zouharova, M. and Rysanek, D. (2008): Multiplex PCR and RPLA Identification of Staphylococcus aureus enterotoxigenic strains from bulk tank milk. Zoonoses Pub. Health, 55:313-319. 